Editorial

\title{
Ventricular arrhythmias and sudden cardiac death in patients with chagas disease
}

Volume 8 Issue 6 - 2017

\begin{abstract}
Editorial
Chagas disease is a parasitic zoonosis caused by Trypanosoma cruzi which is transmitted by insects belonging to different species of Triatoma. Nevertheless, several other routes of transmission have also been described, such as transmission via blood transfusion, infected organs transplant, and oral transmission..$^{1-5}$ Following the acute phase of the infection, untreated Chagas' disease enters a chronic phase that is initially asymptomatic or unrecognized. It is estimated that nearly one third of the patients infected with T. cruzi will develop symptomatic heart disease during the course of their lives..$^{6-10}$ The pathogenesis of the Chagas heart disease (CHD) is not clearly understood yet. Current knowledge of the physiopathology of this disease, as well as, the scientific understanding of the medical based evidence points towards a complex etiology. There is evidence of direct involvement of parasites in producing myocardial damage. ${ }^{11-14}$ The possibility of a mechanism associated to autoimmune phenomenon was also described. ${ }^{15-18}$ Other described pathogenic mechanisms include microvascular alterations and autonomic denervation. ${ }^{19-21}$
\end{abstract}

Carlos Chagas described the disease that bears his name in 1909. The next year he emphasized the importance of the abnormalities in the cardiac rhythm found in some patients with chronic disease. Hence, he then already suggested the existence of heart involvement in patients with chronic Chagas disease. ${ }^{22-25} \mathrm{He}$ noticed the presence of premature ventricular contractions (PVC) and stressed the presence of AV block in cases of extreme bradycardia during physical examination as cause of abnormalities in the cardiac rhythm. Carlos Chagas presented cases of patients with heart failure and frequent PVC who were found to have nests of parasites accompanied by interstitial mononuclear cell infiltration in the myocardium at autopsy. ${ }^{26-28}$ Therefore, he suggested that PVC on physical examination could herald sudden cardiac death (SCD) in the cardiac form of the chronic disease..$^{29-31}$

Low LV ejection fraction and VO2 max remained independent predictors of all cause mortality in patients with chronic heart failure secondary to chronic CHD. In addition, ventricular tachycardia induced by exercise stress testing was found to be a predictor of sudden cardiac death in patients with chronic CHD. ${ }^{32-36}$ Rochitte et al., ${ }^{37}$ quantified myocardial fibrosis by magnetic resonance imaging in patients with chronic CHD. They observed that myocardial fibrosis was present in $85 \%$ of patients with this condition, and that LV ejection fraction was inversely correlated to myocardial fibrosis. The authors demonstrated that myocardial fibrosis was present in all patients with ventricular tachycardia, a fact that strongly suggest a role for the fibrosis in the pathogenesis of malignant arrhythmias in patients with chronic $\mathrm{CHD}{ }^{37}$

Chagas heart disease is a fibrotic disease that is generally located in the posteroinferior and apical region of the left ventricle, the sinus node, and the conduction system below the bundle branch. CHD often develop as a form of dilated cardiomyopathy with a tendency towards the formation of apical aneurysms. It has a powerful arrhythmogenic potential leading to ventricular arrhythmias and sudden cardiac

\author{
Osmar Antonio Centurión, Laura Beatriz \\ García \\ Department of Health Sciences?s Investigation, Sanatorio \\ Metropolitano, Fernando de la Mora, Paraguay
}

Correspondence: Osmar Antonio Centurión, Professor of Medicine,Asuncion National University, Department of Health Sciences $\square$ s Investigation, Sanatorio Metropolitano, Teniente Ettiene $215 \mathrm{c} /$ Ruta Mariscal Estigarribia, Fernando de la Mora, Paraguay, Email osmarcenturion@hotmail.com

Received: April 27, 2017 | Published: May 05, 2017

death. Also CHD is often associated with bradyarrhythmias due to atrioventricular block or sinus node disease. In the natural course of the disease, the cardiac abnormalities appear progressively around 20 to 30 years following infection. ${ }^{21,22}$ On the other hand, during the acute phase of the infection nearly $10 \%$ of the patients develop myocarditis that progresses rapidly towards a severe form of CHD. ${ }^{38,39}$ Other patients with mild cardiac involvement who are in the chronic phase of the disease may develop sudden exacerbation and acute heart failure when exposed to conditions of immunosuppression. ${ }^{39}$

There is no characteristic pattern of CHD in the conventional electrocardiogram. However, an isolated right bundle-branch block or its association with left anterior hemiblock in patients with positive serology can be considered indicators of chronic CHD. ${ }^{40-42}$ Patients with symptomatic CHD should be considered to be at increased risk of SCD. It is important to remember that SCD can often be the first manifestation of CHD. ${ }^{43,44}$ It was observed that during the chronic phase of the clinical evolution of the patients suffering from CHD, some of them died suddenly and unexpectedly. Unexpected SCD is one of the main mechanisms of mortality in patients suffering from Chagas disease. SCD occurs in a significant number of subjects in whom no previous symptoms or relevant symptoms were detected during clinical follow-up. ${ }^{43,44}$ The presence of repolarization disorders have been described preceding sudden and global asynchrony. The dispersion of the QT interval is present in 20-30\% of infected subjects not suffering from any other symptoms. Therefore, it is necessary to evaluate the dispersion of the QT interval and variability of the heart rate in Chagas disease since its association with ventricular arrhythmia and sudden unexpected death in patients infected with $\mathrm{T}$. cruzi has been proven. ${ }^{7-9}$

In this setting even nonspecific symptoms as weakness or dizziness have much more significance as they may be predictive of an episode of syncope. Patients with CHD often develop premature 
ventricular contractions and tachycardias, most commonly associated with myocardial damage that generates reentry phenomena. Most sustained ventricular tachyarrhythmias in patients with CHD do not arise from the apical aneurysm of the left ventricle but rather from the inferolateral region. ${ }^{45,46}$ Since these malignant arrhythmias develop within a progressive abnormality with multiple arrhythmogenic foci, radiofrequency ablation is not so effective and should not be considered as first choice therapeutic technique. Despite the absence of specific studies in chronic CHD, the implantation of an implantable cardioverter defibrillator (ICD) is recommended to reduce the risk of sudden death in cases of clinical sustained ventricular tachycardia, or in monomorphic sustained ventricular tachycardia developing during the electrophysiological study. The administration of amiodarone is a possibility in patients with nonsustained ventricular tachycardia and normal noninducible electrophysiological study. Amiodarone is also administered empirically in an effort to reduce the frequency of appropriate or inappropriate ICD discharges and lower the likelihood of electrical storm. If the patient receives too many discharges despite this pharmacological treatment, radiofrequency ablation should be considered. ${ }^{47,48}$

\section{Acknowledgments}

None.

\section{Conflicts of interest}

Author declares there are no conflicts of interest.

\section{Funding}

None.

\section{References}

1. Kun H, Moore A, Mascola L, et al. Transmission of Trypanosoma cruzi by heart transplantation. Clin Infect Dis. 2009;48(11):1534-1540.

2. Murcia L, Carrilero B, Saura D, et al. Diagnóstico y tratamiento de la enfermedad de Chagas. Enferm Infecc Microbiol Clin. 2013;31(Supl 1):26-34.

3. Pérez-Molina JA, Norman F, López-Vélez R. Chagas disease in nonendemic countries: Epidemiology, clinical presentation and treatment. Curr Infect Dis Rep. 2012;14(3):263-274.

4. Rassi A, Rassi A, Marin-Neto JA. Chagas disease. Lancet. 2010;375:1388-1402.

5. Rodríguez-Guardado A, Rodriguez M, Alonso P, et al. Serological screening of Chagas disease in an immigrant population in Asturias, Spain proceeding from Chagas-endemic areas. Scand J Infect Dis. 2009;41(10):774-776.

6. Stoloff Groppo A, Higushi L, Bocchi E, et al. Heart Transplantation in patients with Chagas Disease cardiomyopathy. J Heart Transplant. 1987;6(5):307-312.

7. Mitelman J, Giménez L, Romero Villanueva H, et al. Electrocardiografía de alta resolución para la detección de alteraciones funcionales miocárdicas en Chagas indeterminado. Tem de Cardiol. 2004;5:9-12.

8. Mitelman J, Giménez L, Palacios K, et al. Anticuerpos antirreceptores a neurotransmisores y su correlación con la alteración de la dispersión del QT y de la variabilidad de la frecuencia cardíaca. Reblampa . 2006;19(3):408-415.

9. Andres DS, Irurzum IM, Defeo MM, et al. Detecting Subclinical Alterations in Early Stages of Chagas Disease Through Holter. Circulation. 2008;118(12):e258.

10. Ferreira Simao. Chagas Disease and inmunossupression. Mem Inst Oswaldo Cruz, Rio de Janeiro. 1999;94(Supl 1):325-327.
11. Baruch WA, Arribada JA, Bulla DH, et al. Consulta Técnica Regional OPS/MSF sobre Organização e estrutura da atenção médica do doente e infectado por Trypanosoma cruzi/doença de Chagas. Rev Soc Bras Med Trop. 2005;38:538-541.

12. Dias JCP. Natural history of Chagas' disease. Arq Bras Cardiol. 1995;65(4):359-366.

13. Bellotti G, Bocchi EA, De Moraes AV, et al. In vivo detection of Trypanosoma cruzi antigens in hearts of patients with chronic Chagas' heart disease. Am Heart J. 1996;131(2):301-307.

14. Higuchi ML, de Brito $\mathrm{T}$, Reis $\mathrm{MM}$, et al. Correlation between Trypanosoma cruzi parasitism and myocardial inflammatory infiltrate in human chronic chagasic myocarditis: light microscopy and immunohistochemical findings. Cardiovasc Pathol. 1993;2(2):101-106.

15. Takle GB, Hudson L. Autoimmunity and Chagas' disease. Curr Top Microbiol Immunol . 1989;145:79-92.

16. López L, Arai K, Jiménez E, et al. C-Reactive Protein and Interleukin-6 serum levels increase as Chagas disease progreses towards cardiac failure. Rev Esp Cardiol. 2006;59(1):50-56.

17. Rossi MA. Microvascular changes as a cause of chronic cardiomyopathy in Chagas' disease. Am Heart J. 1990;120(1):233-236.

18. Tafuri WL. Immunopathology of Chagas disease: a historical overview. Mem Inst Oswaldo Cruz Suppl. 1999;247-248.

19. Marin-Neto JA. Cardiac dysautonomia and pathogénesis of Chagas' heart disease. Int J Cardiol. 1998;66(2):29-131.

20. Dávila-Spinetti DF, Colmenarez-Mendoza HL, Lobo-Vielma L Mecanismos causantes de la progresión del daño miocárdico en la enfermedad de Chagas crónica. Rev Esp Cardiol. 2005;58(9):1007-1009.

21. Viotti R, Vigliano C, Lococo B, et al. Indicadores clínicos de progresión de la miocaditis chagásica crónica. Rev Esp Cadiol. 2005;58(9):1037-1044.

22. Chagas C. Pathogenic processes of American trypanosomiasis. Mem Inst Oswaldo Cruz. 1916; 8:3-38.

23. Bestetti RB, Martins CA, Cardinalli-Neto A. Justice where justice is due: A posthumous Nobel Prize to Carlos Chagas (1879-1934), the discoverer of American Trypanosomiasis (Chagas' disease). Int $J$ Cardiol . 2009;134(1):9-16.

24. Chagas C. Aspecto clínico geral da nova entidade mórbida produzida pelo Schizotrypanum cruzi (Nota Prévia). Brazil-Médico. 1910;24(27):263-265.

25. Chagas C. Nova entidade mórbida do homem. Brazil-Médico. 1910;45:443-447.

26. Vianna G. Contribuição para o estudo da anatomia patológica de Carlos Chagas. Mem Inst Oswaldo Cruz. 1911;3:276-294.

27. Chagas C. Nova entidade mórbida do homem. Resumo geral de estudos etiológico e clínico. Mem Inst Oswaldo Cruz. 1911;3:3-59.

28. Chagas C. O mal de Chagas. Arch Soc Med Cir S Paulo. 1912;3:34-66.

29. Chagas C. Processos patogênicos da trypanosomiase americana. Mem Inst Oswaldo Cruz. 1916;8:5-35.

30. Bestetti RB, Cardinalli-Neto A, Restini CB, et al. Could Carlos Chagas' assumption on the relationship between goiter and chronic Chagas heart disease be correct? A historical reappraisal. Int J Cardiol . 2016;202:410-412.

31. Chagas C, Villela E. Cardiac form of American Trypanosomiasis. Mem Inst Oswaldo Cruz. 1922;14:5-91.

32. Mady C, Cardoso RH, Barretto AC, et al. Survival and predictors of survival in patients with congestive heart failure due to Chagas' cardiomyopathy. Circulation. 1994;90(6):3098-3102. 
33. de Paola AA, Gomes JA, Terzian AB, et al. Ventricular tachycardia during exercise testing as a predictor of sudden death in patients with chronic chagasic cardiomyopathy and ventricular arrhythmias. Br Heart J. 1995;74(3):293-295.

34. Bestetti RB, Dalbo CM, Arruda CA, et al. Predictors of sudden cardiac death for patients with Chagas' disease: a hospital-derived cohort study. Cardiology. 1996;87(6):481-487.

35. Cabot R. The four common types of heart-disease. JAMA 2014;63(17):1461-1463.

36. Sánchez G, Coronado X, Zulantay I, et al. Monitoring the efficacy of specific treatment in chronic Chagas disease by polymerase chain reaction and flow cytometry analysis. Parasite. 2005;12(4):353-357.

37. Rochitte CE, Oliveira PF, Andrade JM, et al. Myocardial delayed enhancement by magnetic resonance imaging in patients with Chagas' disease: a marker of disease severity. J Am Coll Cardiol. 2005;46(8):1553-1558.

38. Prata A. Prognóstico e complicações da doença de Chagas. Rev Goiana Med. 1959;5:87-96.

39. Simoes MV, Nonino A, Simoes BP, et al. Reagudization of Chagas myocarditis inducing exclusive right ventricular failure. Arq Bras Cardiol. 1994;62(6):435-437.

40. Laranja FS, Dias E, Nobrega G, et al. Chagas' disease: a clinical epidemiologic, and pathologic study. Circulation. 1956;14(6):1035-1060.
41. Maguire JH, Hoff R. Cardiac morbidity and mortality due to Chagas disease: prospective eletrocardiographic study of a Brazilian community. Circulation. 1987;75:1140-1145.

42. Dias JCP, Kloetzel K. The prognostic value of the electrocardiographic features of chronic Chagas'disease. Rev Inst Med Trop São Paulo. 1968;10(3):158-162.

43. Prata A, Lopes ER, Chapadeiro E. Características da morte súbita tida como não esperada na doença de Chagas. Rev Soc Bras Med Trop. 1986;19(1):9-12.

44. Rassi A Jr, Rassi SG, Rassi A. Sudden death in Chagas' disease. Arq Bras Cardiol .2001;76(1):75-96.

45. Oliveira JS, Mello de Oliveira JA, Frederigue U Jr, et al. Apical aneurysm of Chagas' heart disease. Br Heart J. 1981;46:432-437.

46. Sarabanda A, Sosa E, Scanavacca M, et al. Correlação entre a morfologia da taquicardia ventricular sustentada e a ventriculografia esquerda na cardiopatia chagásica crônica. Rev Bras Marcapasso e Arritmias. 1994; $7: 143$.

47. Sosa E, Scalabrini A, Rati M, et al. Successful catheter ablation of the «origin» of recurrent ventricular tachycardia in chronic chagasic heart disease. J Electrophysiol. 1987;1:5861.

48. Sosa E, Scanavacca M, D'Avila A, et al. Radiofrequency catheter ablation of ventricular tachycardia guided by nonsurgical epicardial mapping in chronic chagasic heart disease. Pacing Clin Electrophysiol . 1999;22(1):128-130. 